International Journal of Current Advanced Research

ISSN: O: 2319-6475, ISSN: P: 2319 - 6505, Impact Factor: SJIF: 5.995

Available Online at www.journalijcar.org

Volume 6; Issue 4; April 2017; Page No. 3040-3041

DOI: http://dx.doi.org/10.24327/ijcar.2017.3041.0174

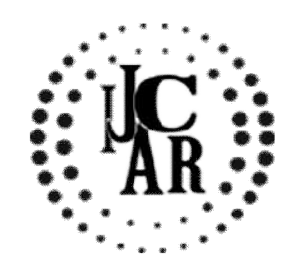

Research Article

\title{
KNOWLEDGE ATTITUDE PRACTICE AMONGST DENTAL PRACTITIONERS REGARDING ORAL MANIFESTATION OF SCARLET FEVER
}

\author{
Meghana Reddy J, Dhanraj and Suresh
}

Saveetha Dental College and Hospitals, Chennai 600007

\section{A R T I C L E I N F O \\ Article History: \\ Received $18^{\text {th }}$ January, 2017 \\ Received in revised form $19^{\text {th }}$ February, 2017 \\ Accepted $15^{\text {th }}$ March, 2017 \\ Published online $28^{\text {th }}$ April, 2017}

\section{Key words:}

Scarlet fever, scarlatina,

Streptococcus pyrogens. \begin{abstract}
A B S T R A C T
Aim: To do a survey on Knowledge Attitude Practice in oral manifestation of scarlet fever amongst the dental practitioners.

Objective: This study investigates on knowledge Attitude Practice in oral manifestation of scarlet fever amongst the dental practitioners.

Background: Scarlet fever is most common in children 5 to 15 years of age. Although scarlet fever was once considered a serious childhood illness, antibiotic treatments have made it less threatening. Still, if left untreated, scarlet fever can result in more-serious conditions.The signs and symptoms include a sore throat, fever, headaches, swollen lymph nodes, and a characteristic rash. The rash is red and feels like sandpaper and the tongue may be red and bumpy.

Conclusion: To keep the dental practitioner aware about the oral manifestation of scarlet fever.
\end{abstract}

Copyright $₫ 2017$ Meghana Reddy J, Dhanraj and Suresh. This is an open access article distributed under the Creative Commons Attribution License, which permits unrestricted use, distribution, and reproduction in any medium, provided the original work is properly cited.

\section{INTRODUCTION}

Scarlet fever, also known as scarlatina, is a disease caused by a toxin released by the bacteria Streptococcus pyrogens, the same organism that causes strep throat. [9] In twentieth century it was leading cause for death in children. The disease is caused by a group A beta-haemolytic streptococcus bacteria, the same bacteria that cause tonsillitis and streptococcal pharyngitis.Scarlet fever occurs when group A streptococcal pharyngitis is caused by a lysogenic strain of the streptococcus bacteria that produce a pyrogenic exotoxin, which causes the rash.[10] This illness affects some people who have strep throats or skin infections which is caused by streptococcus A bacteria this is generally a mild illness, but people with scarlet fever need treatment to prevent rare diseases. Generally doctors treat scarlet fever with antibiotics to reduce the symptoms and to reduce the spread of disease.Although anyone can get scarlet fever it usually effects children between 5 to 15 years. The characteristics symptom of this disease is red rash which fells rough like sandpaper.[1]

It has been shown in previous papers that a specific toxin is present in the blood of patients with scarlet fever during the early acute stage of the disease and that the amount of toxin present varies with in wide limits in different patients.[11] Scarlet fever is a rare disease and was first described in1900.[8]

*Corresponding author: Meghana Reddy J Saveetha Dental College and Hospitals, Chennai 600007
The very rare complications of scarlet fever are acute kidney failure, meningitis, necrotising fasciitis - commonly known as flesh-eating disease, toxic shock syndrome, endocarditis. Symptoms generally occur after 1-4 days after initial infection the first symptoms of scarlet fever are usually a very sore and red throat (sometimes with white or yellowish patches), a fever of 101 Fahrenheit (38.3 Celsius) or higher, frequently with chills. 12-48 hours later, the rash will appear, rash - red blotches appear on the skin; they then turn into a fine pink-red rash that looks like sunburn. The skin feels rough like sandpaper when touched, the rash spreads to the ears, neck, elbows, inner thighs and groin, chest, and some other parts of the body. Although the rash does not usually appear on the face, the patient's cheeks will become flushed, and the area around their mouth becomes pale.[9]

\section{METHODS}

Questionnaires data were collected from 100 dental graduates from several dental colleges. The respondents volunteered to complete the survey after they were informed about the study and received a questionnaire to be filled out. The graduates were asked to answer anonymously and honestly and the return the survey was approximately 5 minutes the questionnaire was divided into 3 parts. Section 1 consisted of 4 question testing the knowledge of dental graduates on Scarlet fever. Section 2 consisted of 3 likert-type question concerning dental graduate's dental practice methods. Section 3 of the survey consisted of 2 likert-type question assessing the attitude of dental graduates towards Scarlet fever. 


\section{RESULTS}
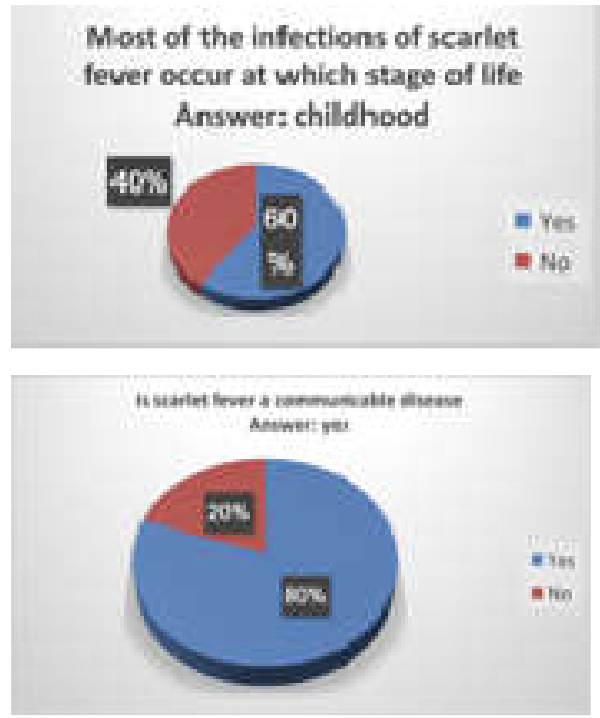

\begin{tabular}{|c|c|c|}
\hline PART B:DENTAL PRACTICE METHODS & YES & NO \\
\hline \multicolumn{3}{|l|}{ - When I treat a patient with scarlet fever } \\
\hline 1) I check the patient history & $8.2 \%$ & $18 \%$ \\
\hline 2) Use proper infection control & $80 \%$ & $20 \%$ \\
\hline 3)I want to educate them about scarlet fever & $80 \%$ & $20 \%$ \\
\hline
\end{tabular}

PART-3: Dental PRACTITIONERS ATTITUDE
TOWARDS THE DISEASE

* When I am treating a patient with scarlet fever.

1) Ifeel uncomfortable.

2)l am concerned about getting infected.

$\begin{array}{ll}40 & 60 \\ \% & \% \\ 75 & 25 \\ \% & \%\end{array}$

\section{CONCLUSION}

From the above data we can conclude that the dental graduates don't have complete knowledge about scarlet fever, know the proper dental practice methods and they don't have confident attitude while attending the scarlet fever patient.

\section{References}

1. "Scarlet Fever: A Group A Streptococcal Infection". Center for Disease Control and Prevention. January 19, 2016. Retrieved 12 March 2016.

2. Sotoodian, Bahman; Rao, Jaggi (9 November 2015). "Scarlet Fever". MedScape. Retrieved 9 January 2016.

3. Yang, S. G.; Dong, H. J.; Li, F. R.; Xie, S. Y.; Cao, H. C.; Xia, S. C.; Yu, Z.; Li, L. J. (2007). "Report and analysis of a scarlet fever outbreak among adults through food-borne transmission in China". Journal of Infection. 55 (5): 419-424. doi:10.1016/j.jinf.2007. 07.011. PMID 17719644
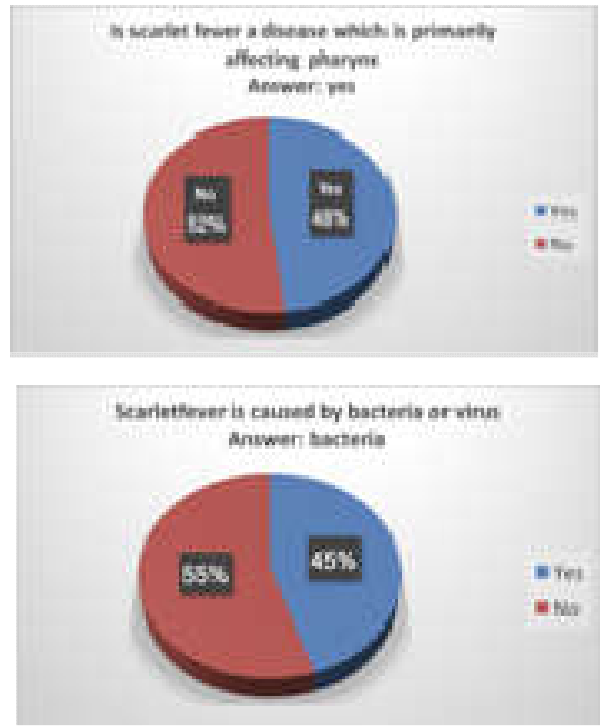

4. Yu CE, Ferretti JJ. Molecular epidemiologic analysis of the type A streptococcal exotoxin (erythrogenic toxin) gene (speA) in clinical Streptococcus pyogenes strains. Infect Immun. 1989 Dec; 57(12):3715-3719. [PMC free article] [PubMed]

5. Zabriskie JB. The role of temperate bacteriophage in the production of erythrogenic toxin by group a streptococci. J Exp Med. 1964 May 1; 119:761-780. [PMC free article] [PubMed]

6. Krejci, L. E., et al. "Studies on the hemolytic streptococcus v. The electrophoretic isolation of the erythrogenic toxin of scarlet fever and the determination of its chemical and physical properties." Journal of Biological Chemistry 142.2 (1942): 785802.

7. Stock, A. H. "Studies on the hemolytic streptococcus iv. Further purification and concentration of scarlet fever toxin." Journal of Biological Chemistry 142.2 (1942): 777-783.

8. Lo, Wen-Tsung, et al. "Panton-Valentine leukocidin is associated with exacerbated skin manifestations and inflammatory response in children with communityassociated staphylococcal scarlet fever." Clinical Infectious Diseases 49.7 (2009): e69-e75.

9. Christian Nordqvist Reviewed by University of Illinois-Chicago, School of Medicine.Scarlet Fever: Causes, Symptoms, and Treatments

10. Cormican, M.G., and M.A. Pfaller. "Molecular Pathology of Infectious Diseases," in Clinical Diagnosis and Management by Laboratory Methods. 20th ed. Philadelphia: W. B. Saunders, 2001.

11. Francis g. Blake and James D. Trask the relation of the specific toxemia of scarlet fever to the course of the disease.

\section{How to cite this article:}

Meghana Reddy J et al (2017) ' Knowledge Attitude Practice Amongst Dental Practitioners Regarding Oral Manifestation Of Scarlet Fever', International Journal of Current Advanced Research, 06(04), pp. 3040-3041.

DOI: http://dx.doi.org/10.24327/ijcar.2017.3041.0174 